\title{
Effects of barite on aspects of the ecology of the polychaete Mediomastus ambiseta
}

\author{
Victoria R. Starczak, Charlotte M. Fuller*, Cheryl Ann Butman \\ Applied Ocean Physics and Engineering Department, Woods Hole Oceanographic Institution, Woods Hole, \\ Massachusetts 02543, USA
}

\begin{abstract}
Barite $\left(\mathrm{BaSO}_{4}\right)$, a major component of drilling muds, can change the texture and erosion properties of surface sediments near offshore drilling sites. The effects of barite on the ecology of the marine polychaete Mediomastus ambiseta (Hartman) were examined in laboratory experiments: a migration experiment, 2 feeding experiments and a growth experiment. In the migration experiment, 18 of 19 worms left $100 \%$ barite within $2 \mathrm{~d}$. This was significantly more worm movement than from natural mud to $100 \%$ barite; only 3 of 15 worms moved into $100 \%$ barite. Worms did not move into $10 \%$ barite sediments, but neither did they show high movement out of $10 \%$ barite. There was no difference in worm movement into and out of $1.0 \%$ barite sediment or natural mud with a $1 \mathrm{~mm}$ barite cover. In 2 separate feeding experiments, lasting $6 \mathrm{~d}$ and $18 \mathrm{~d}$, the mean number of fecal pellets produced per worm per day did not differ between treatments with barite concentrations ranging from $0 \%$ barite (natural mud) to $50 \%$ barite, by weight, and a treatment with a $1 \mathrm{~mm}$ barite layer over mud. In the second feeding experiment, growth (number of setigers added) differed between males and females. Females grew more than males, but growth did not differ between treatments. In the fourth experiment, growth of worms in natural mud did not differ from worms in $10 \%$ barite sediments after 8 wk. Worm tube production (number of tube openings per worm) did not differ between natural mud and barite treatments in the 2 feeding experiments and the growth experiment. These experiments show essentially no deleterious effect on fecal pellet production, growth and tube production of adult $M$. ambiseta living in realistic concentrations of barite found in marine sediments subjected to drilling activity, although worms may migrate out of $100 \%$ barite patches.
\end{abstract}

\section{INTRODUCTION}

Oil exploration and production on the outer continental shelf and slope uses drilling muds (fluids) composed primarily of barite, bentonite clay, lignite, lignosulfonate and additives that are specific for the conditions of each drilling operation. Drilling muds are used to lubricate, cool and support the weight of the drill bit and pipe, to prevent blowouts by balancing subsurface and formation pressures and to transport cuttings to the surface (McGlothin \& Krause 1980, Neff et al. 1987). During drilling operations, large amounts of drilling muds are discharged into the ocean and transported downstream (Ayers et al. 1980, NRC 1983,

\footnotetext{
- Present address: Institute of Marine and Coastal Sciences, Rutgers University, PO Box 231, New Brunswick, New Jersey 08903, USA
}

Boothe \& Presley 1985, Neff et al. 1989). Particulates from drilling muds that settle to the bottom can potentially change the texture, quality and erosional properties of surface sediments.

The largest inert mineral component of drilling muds is barite. It functions as a weighting agent to balance the pressures of drilled formations (Neff et al. 1987). Barite ( 94 to $96 \% \mathrm{BaSO}_{4}$ ) is composed of silt- and claysized particles $(<64 \mu \mathrm{m}$, and $27 \%$ of barite particles $<15 \mu \mathrm{m}$ ) that are almost twice as dense as quartz and insoluble in water (Perricone 1980). Mass particulate concentrations of barium, which composes $59 \%$ of barite, can be 10 to 20 times above ambient concentration near a drilling site, but decrease rapidly with distance from the point of discharge (Neff 1987, Neff et al. 1989). Maximum barium concentrations in the top $2 \mathrm{~cm}$ of sediment from sites adjacent to production and exploratory drilling wells range from about $5000 \mathrm{ppm}$ in the Gulf of Mexico (Gettleson \& Laird 1980) to about 
$10000 \mathrm{ppm}$ in the sediment fine fraction $(<60 \mu \mathrm{m})$ at the drill rig on Georges Bank (Neff et al. 1989). Petrazzuolo (1983) reported barium concentrations in excess of 40000 ppm above background levels in the Gulf of Mexico. Hyland et al. (1990) reported predrilling, ambient barium concentrations of $1000 \mathrm{ppm}$ in the sediments near a hard-substrate drill site in southern Santa Maria Basin (southern California, USA).

At concentrations similar to those reported at drilling sites, barite is nontoxic to most organisms tested (Smith et al. 1982, NRC 1983, Carls \& Rice 1984, Macdonald et al. 1988). A decrease in species number and in the abundances of some species, however, was found in barite treatments in laboratory studies that investigated macrofaunal and meiofaunal benthic communities colonizing sands mixed with barite and sand covered with barite (Tagatz \& Tobia 1978, Cantelmo et al. 1979). Other studies suggest that the effects of barite on larval settlement may differ between species. Larval settlement of the bivalve Mercenaria mercenaria in still water did not differ among $4 \mathrm{~mm}$ barite over mud, $4 \mathrm{~mm}$ barite over sand, all barite or all mud and all sand, but $M$. mercenaria larvae were also nonselective in experiments with natural sediments and glass beads (Bachelet et al. in press). In a laboratory flume experiment, larval settlement of the polychaete Capitella sp. I was significantly lower in mud covered with a $3 \mathrm{~mm}$ layer of barite than in all mud (C. A. Butman \& J. P. Grassle unpubl.). Similar results were found in an experiment with a low-organic glass bead layer over mud and all mud as the 2 treatments. This suggests that larval settlement of Capitella sp. I was lower in barite than all mud because barite is a loworganic sediment. Changes in settlement behavior or survival of organisms are not the only potential effects of barite; other important effects may include reductions in feeding rate, growth and reproduction. In this study the effects of barite on movement, feeding, growth and tube-building behavior were investigated for the subsurface deposit-feeding, capitellid polychaete Mediomastus ambiseta (Hartman).

Mediomastus ambiseta is a common inhabitant of muddy sediments and is a typical opportunistic species, as indicated by its initial response to disturbed conditions, potential for rapid population increase, early maturation and high mortality (Grassle \& Grassle 1974). Populations of this species reach very high densities under organic enrichment (e.g. reviews of Pearson \& Rosenberg 1978, Grassle \& Grassle 1984), but decline in response to additions of No. 2 fuel oil (Sanders et al. 1980, Oviatt et al. 1982, Grassle \& Grassle 1984). This organism rapidly colonizes newly disturbed or defaunated areas (e.g. Dauer \& Simon 1976a, b, Sanders et al. 1980, Grassle \& Grassle 1984), and when abundant, densities of $M$. ambiseta are typi- cally of order $10^{3} \mathrm{~m}^{-2}$ (Grassle \& Grassle 1984, Hyland et al. 1991) to $10^{5} \mathrm{~m}^{-2}$ (Sanders et al. 1980, Butman \& Fuller unpubl.). Densities of shallow-water (of order $10 \mathrm{~m}$ depth) populations along the northeast coast of the United States vary seasonally. Recruitment of individuals generally occurs in late summer, and high mortality occurs in winter (Sanders et al. 1980, Grassle \& Grassle 1984, Butman \& Fuller unpubl.). High organic input may enhance recruitment success, but during summers when benthic respiration exceeds production at high water temperatures dramatic declines have occurred for $M$. ambiseta populations in Narragansett Bay (Rhode Island, USA) (Grassle \& Grassle 1984). Baseline studies of infaunal communities on the outer shelf and slope of the southern portion of Santa Maria Basin, an offshore oil and gas lease site, reveal a gradient of decreasing density of $M$. ambiseta with increasing water depth (over a range of 91 to $565 \mathrm{~m}$ ), which may be explained by a corresponding gradient in dissolved oxygen and organic input (highest values at the shallow sites) (Hyland et al. 1991).

Mediomastus ambiseta lives primarily within the top $2 \mathrm{~cm}$ of sediment in thin-walled, semi-permanent tubes that protrude several nim above the sediment surface. The tubes, which are made of mucus and covered with sediment and fecal pellets, can have multiple openings (Rasmussen 1956, Germano 1983, Grassle \& Grassle 1984). Worms feed head-down in their tubes, and laboratory experiments with dyed sediments showed that worms ingested sediment down to at least $15 \mathrm{~mm}$ (Butman \& Fuller unpubl.). Cylindrical fecal pellets, held together in strings, are egested in discrete piles onto the sediment surface adjacent to the tubes. In laboratory experiments at $20^{\circ} \mathrm{C}$, individuals of this

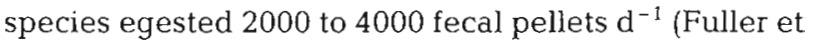
al. 1988). Maximal pellet production occurred between midnight and 06:00 $\mathrm{h}$, and pellet production had a consistent, diurnal cycle. In Buzzards Bay (Massachusetts, USA) at population densities of $10^{6} \mathrm{~m}^{-2}$ an estimated 30 to $100 \%$ of the top $1 \mathrm{~mm}$ of sediment can be pelletized by this species each day (Grant \& Butman 1987).

Mediomastus ambiseta was chosen to test the effects of barite additions to natural sediments on worm movement, feeding rate and growth because (1) it is a typical opportunistic species that can quickly colonize defaunated and disturbed sediments (Grassle \& Grassle 1974 ) adjacent to oil drilling platforms, (2) it occurs naturally in high abundances in muddy outer-shelf and slope sediments that are sites of oil and gas exploration (Hyland et al. 1991), (3) it feeds directly on nearsurface sediments, and (4) there is compelling evidence that organic enrichment to sediments affects recruitment and population dynamics of this species (Grassle \& Grassle 1984). The broad, ecological question underlying this study is whether dilution of natu- 
rally organic-rich sediments by low-organic particles, such as freshly deposited barite, diminishes the food quality of the sediment enough to reduce worm feeding rate, growth and survival such that species distributions are ultimately affected.

This study investigated the effects of barite on migration, defecation rate, growth and tube production of Mediomastus ambiseta. Barite concentrations ranged from natural mud with no addition of barite to $100 \%$ barite in the various experiments. A $1 \mathrm{~mm}$ thick layer of barite over mud was also used to mimic initial barite deposition, for example, directly adjacent to a drilling platform under relatively tranquil conditions before physical or biological mixing can occur.

\section{METHODS}

Natural, organic-rich, muddy sediment for all experiments was collected from the top $2 \mathrm{~cm}$ of Van Veen grabs $\left(0.10 \mathrm{~m}^{2}\right)$ taken in Outer New Bedford Har-

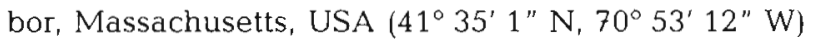
(Table 1$)$. The silt and clay fraction $(<63 \mu \mathrm{m})$ of this mud makes up $76.1 \%$ (by weight) of the particles, and typical percentages by weight of organic carbon, hydrogen and nitrogen in the summer are 3.37, 0.68 and 0.32 , respectively (Bachelet et al. in press). This mud was frozen until $2 \mathrm{~d}$ prior to use in experiments, then thawed at room temperature and mixed with filtered seawater ( $5 \mu \mathrm{m}$ pore size). After $24 \mathrm{~h}$, the mud was passed through a $90 \mu \mathrm{m}$ sieve to remove large particles, e.g. shell debris. The material that passed through the sieve was incubated at $20^{\circ} \mathrm{C}$ for 24 to $30 \mathrm{~h}$ and occasionally stirred until the experiment began.

To prepare sediment treatments, the sieved and incubated mud was centrifuged in a table top clinical centrifuge at maximum speed (ca $4500 \mathrm{rpm}$ ) for $1.5 \mathrm{~min}$, and the overlying water discarded. Dry barite (API Standard; MI Drilling Fluids were obtained from American Petroleum Institute, Dallas, TX, USA) was mixed with seawater, centrifuged and the overlying water discarded. This centrifuged barite was then weighed so that the concentration of barite in sediment was either $0.1,1.0,10.0$, or $50.0 \%$ by weight (or 590 , 5900, 59000, or $295000 \mathrm{ppm}$ barium); the weighed barite was then mixed with mud. Thus, the percent barite in each treatment was a ratio of wet weight of barite to wet weight of mud in all experimental treatments except in the growth experiment where dry barite was weighed and added to centrifuged mud. In this case, the percent barite was a ratio of dry weight to wet weight. Methods for mixing mud and barite differed between experiments and are described below. Sediment treatments were placed in glass Stendor dishes $(4.4 \mathrm{~cm}$ diameter, $2.0 \mathrm{~cm}$ deep) containing a small amount of filtered seawater. For the $1 \mathrm{~mm}$ barite treatment, barite was pipetted onto the mud surface of each dish. Approximately $0.8 \mathrm{~cm}$ of seawater above the sediment surface was added to each dish in all treatments.

Worms were collected from Outer New Bedford Harbor with a Van Veen grab or diver-held cores (Table 1). Sediment from grabs or cores was returned to Woods Hole Oceanographic Institution and washed gently over a $300 \mu \mathrm{m}$ sieve that same day. Worms remaining on the sieve were placed in glass culture dishes (20.3 cm diameter, $7 \mathrm{~cm}$ deep) in $1 \mathrm{~cm}$ of mud and maintained in a $20^{\circ} \mathrm{C}, 14 / 10 \mathrm{~h}$ light/dark incubator until use in the experiments. Once or twice a month, water in culture dishes was changed, and worms were fed with 10 to $15 \mathrm{ml}$ of thawed mud.

Whole, adult worms were sieved out of the laboratory cultures and removed from their tubes. One worm was placed on the sediment in each dish except in the migration experiment where 5 worms were added to each dish. Every second or third day in the growth and in the migration experiments and daily in the feeding experiments, fecal pellet piles produced by the worms were carefully pipetted from the sediment surface and fresh filtered seawater was added.

Table 1. Dates that mud and worms were collected and processed for each experiment and the duration of the setup procedures. Sediment was incubated at $20^{\circ} \mathrm{C}$

\begin{tabular}{|c|c|c|c|c|c|c|c|}
\hline Experiment & $\begin{array}{l}\text { Worms } \\
\text { collected }\end{array}$ & $\begin{array}{c}\text { Mud } \\
\text { collected }\end{array}$ & $\begin{array}{c}\text { Mud } \\
\text { thawed }\end{array}$ & $\begin{array}{l}\text { Mud } \\
\text { incubated }\end{array}$ & $\begin{array}{l}\text { Treatment } \\
\text { set-up }\end{array}$ & $\begin{array}{l}\text { Worms } \\
\text { added }\end{array}$ & $\begin{array}{l}\text { Experiment } \\
\text { ended }\end{array}$ \\
\hline Migration & 7 Jul 1989 & 29 Jun 1989 & 28 Jul 1989 & $24 h+56 h$ & 1 Aug 1989 & 2-3 Aug 1989 & 11 Aug 1989 \\
\hline \multicolumn{8}{|l|}{ Feeding } \\
\hline First & 19 Sep 1988 & 30 Jun 1988 & 28 Sep 1988 & $21 h+30 h$ & 30 Sep 1988 & 30 Sep 1988 & 6 Oct 1988 \\
\hline Second & 31 May 1989 & 31 May 1989 & 14 Jun 1989 & $24 h+24 h$ & 16 Jun 1989 & 16 Jun 1989 & 28 Jun 1989 \\
\hline Growth & 19 Sep 1988 & 30 Jun 1988 & $21 \operatorname{Jan} 1989$ & $24 h+24 h$ & $24 \operatorname{Jan} 1989$ & $24 \operatorname{Jan} 1989$ & 21 Mar 1989 \\
\hline
\end{tabular}


Experiments were conducted at $20^{\circ} \mathrm{C}$ in a $14 / 10 \mathrm{~h}$ light/dark incubator.

Migration experiment. Two hypotheses were tested concerning movement of worms into and out of sediments containing barite. The first hypothesis was that the number of worms that left barite sediments for all mud would be greater than the number of worms that left all mud for barite sediments. If barite negatively affected worms, then fewer worms would be in barite sediments than in the all mud sediments after $7 \mathrm{~d}$. The second hypothesis was that worm movement into all mud would be greater from all mud than worm movement out of all mud into sediments containing barite. If barite had a negative effect on worms, then the number of worms that left mud for barite sediments would be less than the number of worms that left one side of the mud control dish for the other side after $7 \mathrm{~d}$.

To test these 2 hypotheses, treatments were designed to have 4 replicate dishes with 2 types of mud in each dish. Dishes had all mud on one side of a plastic barrier and either all mud (control), or 1, 10, 100\% barite or $1 \mathrm{~mm}$ barite cover over all mud on the other side of the barrier. The barrier was removed after the worms were added to one side of each dish, and the location of the worms after $7 \mathrm{~d}$ was recorded.

In an unreplicated preliminary experiment, some worm tubes were found in the $100 \%$ barite sediments, but worm fecal pellets were all mud indicating that the worms were feeding in mud and not in the barite. Therefore, to check whether worms were feeding in barite sediments in the present experiment, fluorescent paint particles, $1 \%$ by weight, were mixed with mud used in the barite treatments. (Fluorescent particles are visible with ultraviolet light and are incorporated into fecal pellets by Mediomastus ambiseta without affecting worm fecal pellet production rates; Butman \& Fuller unpubl.). Sediments containing barite were mixed with orange-fluorescing particles, and the all mud sediments were mixed with blue-fluorescing particles.

Barite treatments were made by first mixing mud with orange-fluorescing particles, centrifuging and then mixing barite with $147.5 \mathrm{~g}$ of this mud to make $1.0 \%$ barite by weight. Another $129.6 \mathrm{~g}$ of this mud was mixed with barite for the $10.0 \%$ barite treatment. Mud and barite were stirred and shaken with seawater for $1 \mathrm{~min}$ and then added to the dishes. For the all mud sediments, mud was mixed with blue-fluorescing particles before being centrifuged. Thus, dishes for the barite treatments had barite mixed with mud and orange particles on one side of a barnier and mud mixed with blue particles on the other side of the barrier. Dishes for the control, where all mud was on both sides of a barrier, had mud mixed with orange particles on one side of the barrier and with blue particles on the other side. Dishes containing the $1 \mathrm{~mm}$ barite cover treatment consisted of all mud mixed with blue particles on one side of the barrier, and mud mixed with orange particles and covered by a $1 \mathrm{~mm}$ layer of barite on the other side.

The experimental procedure was to insert a plastic barrier into each dish, add treatment sediments to $8.0-13.0 \mathrm{~mm}$ depth, add ca $5 \mathrm{~mm}$ of filtered seawater over the sediment surface of each dish, and incubate the dishes at $20^{\circ} \mathrm{C}$ overnight (Table 1). The next day, a $1 \mathrm{~mm}$ layer of barite was added to the appropriate sides of dishes for the $1 \mathrm{~mm}$ barite cover treatment. For each treatment, worms were added to the barite side in 4 dishes, and worms were added to the mud side in 4 other dishes. In the 4 control dishes, worms were added to one side. Because of time constraints, only 4 worms were added to each dish for all treatments in one day; the following day 1 additional worm was added to each dish to make a total of 5 worms on one side of each dish at the start of the experiment. Worms were allocated to dishes randomly on both days. To reduce any potential effects of differential lighting in the incubator, dishes were placed in 4 rows parallel to the light in the incubator door. One replicate dish from each treatment was assigned at random to a row and to a position within the row. After $24 \mathrm{~h}$, location and color of fecal mounds in each dish were recorded, and the barrier was removed. Location and color of fecal mounds was again recorded $24 \mathrm{~h}$ later. Seven days after the barrier was removed, mounds were surveyed for location and color, and the barrier was reinserted. Sediment from each side of the dish was sieved to recover the worms.

Although we attempted to place 5 worms in every dish, worms sometimes stuck to forceps and were not added to the dish they were designated for. Also, worms that built tubes onto the plastic barriers may have been removed with the barriers. On recovery, there was an average of 4.6 worms per dish. One dish had 2 worms, and 5 dishes had 6 worms. Because the number of worms in each dish was too small to treat the dishes as replicates in a statistical analysis, the results from the 4 replicate dishes for each treatment were combined to test the 2 hypotheses.

Feeding experiments. Two experiments were performed to determine whether fecal pellet production rate, a proxy for feeding rate (e.g. Taghon \& Jumars 1984, Miller \& Jumars 1986, Forbes \& Lopez 1987), differed between natural mud and sediments containing barite. The first experiment was conducted for $6 \mathrm{~d}$ with the following treatments: control (all mud), 0.1 and $1.0 \%$ barite, and $1 \mathrm{~mm}$ barite cover over mud. For the barite treatments, $20 \mathrm{~g}$ of centrifuged mud were added to each dish (Table 1). Then barite, which had been 
mixed with seawater and centrifuged, was added by weight and mixed with the mud to achieve the desired percentage concentrations. Next, 1 worm was placed in each dish, and after $37 \mathrm{~h}$, fecal pellets were removed and seawater was added to replace any seawater removed with the pellets. Twenty-four hours later and every $24 \mathrm{~h}$ for the next $3 \mathrm{~d}$, fecal pellets were collected and counted.

Differences in the pellet production rates between the treatments were tested with a univariate, 2 -factor (i.e. treatment and time), repeated-measures ANOVA. model (Winer 1971).

The second experiment was conducted for $18 \mathrm{~d}$ to determine whether pellet production rates differed between barite treatments when worms were in barite for longer than $6 \mathrm{~d}$. In addition to the treatments in the first feeding experiment, 2 treatments with higher concentrations of barite, 10 and $50 \%$ barite, were included. Barite treatments were made by shaking and stirring $40 \mathrm{~g}$ of centrifuged mud with the appropriate weight of centrifuged barite and seawater for 1 min (Table 1). This mixture was spooned into the dishes to make an 8 to $13 \mathrm{~mm}$ deep layer, and filtered seawater was added over the surface.

To reduce potential variability in pellet production rates due to gender differences between worms, 3 males and 3 females were selected for each treatment. Gender was determined by checking each worm under a dissecting microscope for eggs or sperm. When gametes were examined at the end of the experiment, however, we discovered that the gender of some of the worms was misidentified at the start of the experiment. This problem occurred because very small eggs were difficult to distinguish from sperm. Consequently, the sex ratio of males to females differed between treatments. The control and 1.0\% barite treatments had 3 males and 3 females. Two males and 4 females were used in the 0.1, 10, and $50 \%$ barite treatments, and 1 female and 5 males in the $1 \mathrm{~mm}$ barite cover treatment.

The experimental procedure was similar to the first feeding experiment. Pellets were collected and seawater was added to each dish $38 \mathrm{~h}$ after worms were introduced into the treatment dishes. Twenty-four hours later, pellets were collected and stored at $10^{\circ} \mathrm{C}$ until they were counted. Pellets were collected for counting every $24 \mathrm{~h}$ for 3 more days and every $4 \mathrm{~d}$ for 3 more sampling times. Stored pellets were counted within $48 \mathrm{~h}$ of collection. Although pellets were only enumerated on 7 dates, pellets were removed and filtered seawater was added daily in each dish.

Two methods were used to count pellets. In the first experiment, all pellets were counted visually. Because this method was exceedingly tedious and time consuming, pellets were counted with a Coulter Counter
( 256 channels, and $3200 \mu \mathrm{A}$ current) in the second experiment. Pellet sizes ranged from $160 \times 70 \mu \mathrm{m}$ (length $\times$ width) to $220 \times 100 \mu \mathrm{m}$ with an average of $180 \times$ $75 \mu \mathrm{m}$ ( $\mathrm{n}=3$ worms, 100 pellets per worm). The equivalent spherical volume for the average pellet size was $57.5 \mu \mathrm{m}^{3}$, so a $400 \mu \mathrm{m}$ aperture with a $40 \mu \mathrm{m}$ threshold was used in the Coulter Counter. For 19 samples in the second experiment, pellets were counted using both methods, and a linear regression of the data revealed that the Coulter Counter data could be predicted from the visual counts $\left(y=501.2+0.92 x, F_{1,17}=103.3, p<\right.$ $0.001, \mathrm{R}^{2}=0.86$ ). This model was used to estimate Coulter Counter values for 18 samples that were counted only visually in the second experiment.

Pellet production rates in the second experiment were analyzed with a univariate, 3-factor (treatment, gender and time), repeated-measures ANOVA model (Winer 1971) using Coulter Counter pellet counts as the dependent variable.

To determine whether worm growth rate was affected by worms feeding in barite sediments, growth rate was measured by counting the number of setigers for each worm at the beginning and the end of the second feeding experiment. Number of setigers was analyzed with the same repeated-measures model as above. At the end of the experiment, 1 male in $1.0 \%$ barite was broken into several pieces and could not be sized accurately. This worm was excluded from the analysis on growth.

Qualitative observations of worms in preliminary experiments suggested that worms in sediments containing barite may build more branches per tube than worms in natural mud. Hence, in both feeding experiments, tube production in the different treatments was quantified at each sampling interval. Because it was difficult to determine whether a tube had more than one opening, each tube opening was counted as a separate tube unless multiple openings were visible on a tube. The total number of tube openings per worm at the end of the experiment was used to test whether tube production differed between treatments.

To determine whether sediment containing barite had less food available for deposit feeders than the control, total microbial biomass in the sediment was measured and compared between treatments of the first feeding experiment. Microbial biomass was also measured at the start and the end of the experiment, so that changes over time could be compared with potential changes in pellet production. Before worms were added to treatments, the mud in each dish was mixed and 0.5 to $1.5 \mathrm{~cm}^{3}$ of sediment was collected, fixed in a vial with 5 to $10 \%$ formalin and refrigerated. At the end of the experiment, another 0.5 to $1.5 \mathrm{~cm}^{3}$ sample was collected, fixed and refrigerated. One sample was taken in each dish at each time, but 4 of the 5 samples 
from $1 \%$ barite were lost. The $1 \mathrm{~mm}$ barite cover treatment was sampled only at the end of the experiment. In this treatment, a sample was taken from the top $1 \mathrm{~mm}$ of each dish, and another sample was taken from the mud underneath.

Total phospholipid phosphate (nmol $\mathrm{cm}^{-3}$ of sediment) in each sample was used to estimate total microbial biomass. Lipids were extracted with dicholormethane-methanol, and total phospholipid phosphate determined with methods described by Findlay et al. (1989). For each sample, the volume $\left(\mathrm{cm}^{3}\right)$ of extracted sediment was estimated from the dry weight of extracted sediments using a linear regression computed from known volumes and weights of dried mud. A separate regression model was computed from known volumes and weights of dried barite and was used to estimate volume $\left(\mathrm{cm}^{3}\right)$ of the barite samples taken in the $1 \mathrm{~mm}$ barite layer.

Growth experiment. Although worm growth was measured in the second feeding experiment, this $18 \mathrm{~d}$ experiment may not have been long enough to detect the effects of barite on growth. Consequently, an experiment of longer duration was designed to compare growth in the $10 \%$ barite treatment with that in the control (all mud). Mud (10 g) was added to each of 10 dishes, and $10 \%$ dry barite, by weight, was added with filtered seawater to 5 of the dishes. Sediments in the control and treatment dishes were then mixed and incubated (Table 1).

The number of setigers in each of 10 nonreproductive (no visible gametes) worms was counted, and 1 worm was haphazardly assigned to each dish. Two days later and every 2 or $3 \mathrm{~d}$ until the end of the experiment, the number of tube openings was counted using the same criteria as in the feeding experiments. After 8 wk the number of tube openings was counted, worms were removed from dishes, and the number of setigers per worm was counted. Presence of visible (under a dissecting microscopel gametes and gender of each worm were also noted.

A univariate, 2 -factor (treatment and time) repeatedmeasures ANOVA model was used to test for treatment effect on setiger number (Winer 1971).

\section{RESULTS}

\section{Migration experiment}

The first prediction, that worms were more likely to move from barite sediments into mud than they were to move out of mud into barite sediments, was supported for the $100 \%$ barite treatment. Significantly more worms, $94.8 \%$ (18 of 19 worms), moved from $100 \%$ barite into all mud than from all mud into $100 \%$

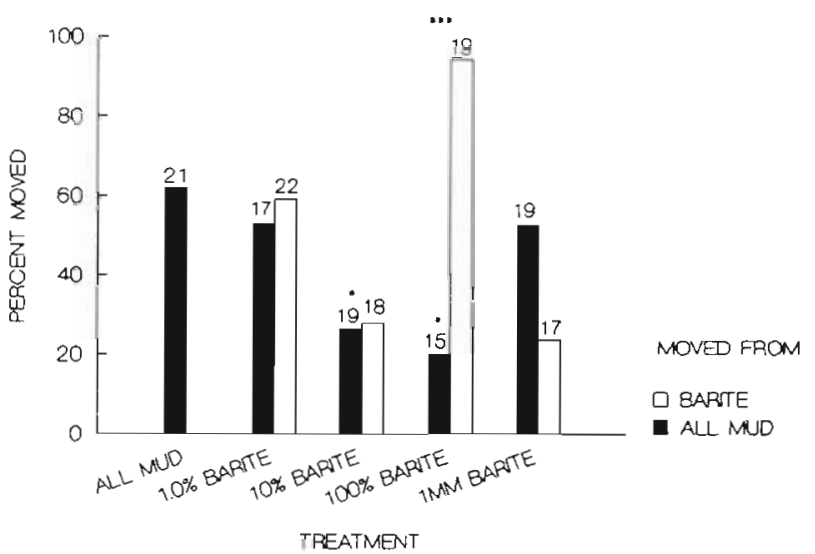

Fig. 1. Mediomastus ambiseta. Percent of worms that moved from the initial side of the dish to the opposite side for each treatment. Open bars: treatments where worms were initially placed in barite; black bars: treatments where the worms were initially placed in mud. Numbers over bars: total number of worms in each treatment. Fisher's Exact tests were used to test the first hypothesis, i.e. open vs black columns; the only significant result was for $100 \%$ barite treatment, $\cdots p<0.001$. Fisher's Exact tests were used to test the second hypothesis, i.e. the all mud treatment vs each of the other black bars; 2 tests were significant, $0.01<p<0.05$, for $100 \%$ barite and $10 \%$ barite

barite ( 3 of 15 worms or $20 \%$; Fig. 1 ). Thus, in this treatment, 4 out of 34 worms were found in $100 \%$ barite at the end of the experiment. All 4 worms, however, had blue fluorescent particles (the label for all mud) in their fecal pellets, indicating that they were feeding on the all mud and not on the $100 \%$ barite. A census of worm fecal piles and tubes revealed that movement of worms out of $100 \%$ barite occurred within $2 \mathrm{~d}$ of barrier removal.

The first prediction was not supported for worms in $10 \%$ barite, $1.0 \%$ barite, $0.1 \%$ barite and the $1 \mathrm{~mm}$ barite cover. Approximately $27 \%$ of the worms moved in both $10 \%$ barite treatments, and $56 \%$ moved in both $1 \%$ barite treatments (Fig. 1). Movement in the $1 \mathrm{~mm}$ barite cover treatment was more variable; $23.4 \%$ (4 out of 17) of the worms initially in $1 \mathrm{~mm}$ barite cover left the barite side of the dish, and $53 \%$ (10 out of 19) of the worms initially in all mud moved into the barite side.

The second prediction, that worms were less likely to move from mud into barite sediments than from one side of the control dishes to the other side, was supported for the $100 \%$ barite and $10 \%$ barite treatments. In control dishes, $62 \%$ (13 out of 21 worms) of the worms were found in the opposite side of the dish at the end of the experiment (Fig. 1). Significantly fewer worms in $10 \%$ barite and $100 \%$ barite treatments, however, moved from all mud into the barite treat- 
ments than worms in control dishes moved from one side to the other. In contrast, there was no significant difference between the worm movement in control dishes and worm movement into the $1 \%$ barite sediment or into the $1 \mathrm{~mm}$ barite cover treatment.

Orange particles (the label for sediments with barite) were found in the fecal pellets of all treatments except $100 \%$ barite. This result indicated that worms fed in sediments containing barite concentrations of 10 or $1 \%$, but not $100 \%$. Worms in the side of the dish with $1 \mathrm{~mm}$ barite cover had orange fluorescent particles (the label for mud underneath the barite layer) in their fecal pellets; thus, worms were feeding in the mud underneath the $1 \mathrm{~mm}$ barite layer.

Table 2. Mediomastus ambiseta. Results of repeated measures ANOVA for both feeding experiments testing whether mean number of pellets produced differed between treatments or between sampling dates. In the second experiment, the difference in feeding rates between males and females is also tested

\begin{tabular}{|lrrrc|}
\hline Source & df & MS & F-ratio & $p$ \\
\hline First feeding experiment & & & & \\
Treatment & 3 & 2341420 & 1.43 & 0.270 \\
Worms (Treatment) & 16 & 1632150 & & \\
Time & 3 & 273817 & 0.98 & 0.410 \\
Time $\times$ Treatment & 9 & 318339 & 1.14 & 0.355 \\
Error & 48 & 279563 & & \\
Second feeding experiment & & & \\
Treatment & 5 & 635071.3 & 0.38 & 0.856 \\
Gender & 1 & 150983.8 & 0.09 & 0.766 \\
Treatment $\times$ Gender & 5 & 992160.9 & 0.60 & 0.703 \\
Worms (Treat. $\times$ Gend.) & 23 & 1664874.0 & & \\
Time & 6 & 1129118.6 & 1.90 & 0.085 \\
Time $\times$ Treatment & 30 & 715218.3 & 1.20 & 0.236 \\
Time $\times$ Gender & 6 & 516752.9 & 0.87 & 0.519 \\
Time $\times$ Gend. $\times$ Treat. & 30 & 627352.4 & 1.06 & 0.401 \\
Error & 138 & 594628.0 & & \\
& & & & \\
\hline
\end{tabular}

\section{Feeding experiments}

The migration experiment demonstrated that worms fed in sediments containing concentrations of barite as high as $10 \%$, and worms fed in mud underneath a $1 \mathrm{~mm}$ barite cover. The feeding experiments were designed to test whether worm feeding rates in mud differed from sediments containing barite. The results were consistent for both feeding experiments; the mean number of fecal pellets produced in any of the barite treatments did not differ significantly from controls.

In the first feeding experiment, one of the worms in the control did not begin producing fecal pellets until the 2nd day of the experiment. There was no significant difference in pellet production between treatments or over time when this worm was included in the analysis (Table 2), and the results did not change when the data for this worm were excluded from the analysis. Worms produced an average of $2698 \pm 117$ pellets $\mathrm{d}^{-1}$ (mean $\pm \mathrm{SD}, \mathrm{n}=4 \mathrm{~d}$ ) averaged over all treatments (Table 3 ). In the second experiment, there was also no significant treatment effect (Table 2). Furthermore, feeding rates did not differ significantly between males and females (Tables $2 \& 4$ ); worms averaged $3583 \pm 194$ pellets $d^{-1}(n=7 d)$. There was no significant treatment-by-time interaction or time effect in either experiment (Table 2).

There was significant worm growth in the second feeding experiment (Table 5); females grew more than males (Table 6). Males and females did not differ in mean setiger number at the start of the experiment; males had $52.8 \pm 5.1(n=16)$ setigers, and females had $52.6 \pm 7.9(n=19)$ setigers. By the end of the experiment, however, females added $15.2 \pm 5.0$ setigers ( $\mathrm{n}=$ 19) while males added $11.2 \pm 4.6$ setigers $(n=16)$. Barite did not significantly affect growth rate in this experiment; there was no significant treatment-by-

Table 3. Mediomastus ambiseta. Mean (SD) number of fecal pellets produced in each treatment at each sampling time in the first feeding experiment. $\mathrm{n}=5$ for the first 4 treatments

\begin{tabular}{|c|c|c|c|c|c|}
\hline \multirow{2}{*}{$\begin{array}{l}\text { Time } \\
\text { (d) }\end{array}$} & \multicolumn{5}{|c|}{ Treatment } \\
\hline & Control & $0.1 \%$ barite & $1.0 \%$ barite & $1 \mathrm{~mm}$ barite & Control ${ }^{a}$ \\
\hline 1 & $\begin{array}{c}2165.2 \\
(1277.7)\end{array}$ & $\begin{array}{l}2704.6 \\
(506.3)\end{array}$ & $\begin{array}{l}2681.0 \\
(845.8)\end{array}$ & $\begin{array}{l}3121.6 \\
(509.3)\end{array}$ & $\begin{array}{l}2706.5 \\
(472.5)\end{array}$ \\
\hline 2 & $\begin{array}{l}2788.8 \\
(719.3)\end{array}$ & $\begin{array}{l}2726.6 \\
(453.8)\end{array}$ & $\begin{array}{l}2306.4 \\
(934.9)\end{array}$ & $\begin{array}{l}3029.2 \\
(490.3)\end{array}$ & $\begin{array}{l}3053.8 \\
(471.1)\end{array}$ \\
\hline 3 & $\begin{array}{l}2649.4 \\
(638.6)\end{array}$ & $\begin{array}{c}2550.0 \\
(1278.4)\end{array}$ & $\begin{array}{c}1881.0 \\
(1226.1)\end{array}$ & $\begin{array}{l}3173.2 \\
(361.2)\end{array}$ & $\begin{array}{l}2903.0 \\
(339.1)\end{array}$ \\
\hline 4 & $\begin{array}{l}2770.4 \\
(667.6)\end{array}$ & $\begin{array}{l}2626.0 \\
(543.1)\end{array}$ & $\begin{array}{l}2603.6 \\
(797.3)\end{array}$ & $\begin{array}{l}3383.2 \\
(360.1)\end{array}$ & $\begin{array}{l}3017.3 \\
(433.6)\end{array}$ \\
\hline
\end{tabular}


Table 4. Mediomastus ambiseta. Mean (SD) number of fecal pellets produced in each treatment at each sampling time in the second feeding experiment for males and females; $\mathrm{n}=$ sample size

\begin{tabular}{|c|c|c|c|c|c|c|}
\hline \multirow{2}{*}{$\begin{array}{l}\text { Time } \\
\text { (d) }\end{array}$} & \multicolumn{6}{|c|}{ Treatment } \\
\hline & Control & $0.1 \%$ barite & $1.0 \%$ barite & $10.0 \%$ barite & $50.0 \%$ barite & $1 \mathrm{~mm}$ barite \\
\hline Males & $(n=3)$ & $(n=2)$ & $(\mathrm{n}=3)$ & $(n=2)$ & $(n=2)$ & $(n=5)$ \\
\hline 1 & $\begin{array}{l}3663.7 \\
(707.5)\end{array}$ & $\begin{array}{l}3809.5 \\
(598.9)\end{array}$ & $\begin{array}{l}4142.3 \\
(482.9)\end{array}$ & $\begin{array}{l}3850.5 \\
(122.3)\end{array}$ & $\begin{array}{l}3527.5 \\
(890.2)\end{array}$ & $\begin{array}{c}3506.2 \\
(1396.3)\end{array}$ \\
\hline 2 & $\begin{array}{c}4726.3 \\
(2495.5)\end{array}$ & $\begin{array}{c}3108.5 \\
(1402.2)\end{array}$ & $\begin{array}{l}3697.3 \\
(476.1)\end{array}$ & $\begin{array}{l}4055.5 \\
(565.0)\end{array}$ & $\begin{array}{c}2240.0 \\
(1240.3)\end{array}$ & $\begin{array}{l}2385.6 \\
(839.5)\end{array}$ \\
\hline 3 & $\begin{array}{l}3757.3 \\
(568.4)\end{array}$ & $\begin{array}{l}3950.5 \\
(535.3)\end{array}$ & $\begin{array}{l}3799.3 \\
(872.7)\end{array}$ & $\begin{array}{c}3446.5 \\
(1041.6)\end{array}$ & $\begin{array}{c}4667.0 \\
(2568.6)\end{array}$ & $\begin{array}{l}3674.2 \\
(982.3)\end{array}$ \\
\hline 4 & $\begin{array}{l}3834.3 \\
(781.6)\end{array}$ & $\begin{array}{c}2811.0 \\
(1630.6)\end{array}$ & $\begin{array}{l}3092.3 \\
(179.7)\end{array}$ & $\begin{array}{l}3322.0 \\
(162.6)\end{array}$ & $\begin{array}{l}3950.0 \\
(811.8)\end{array}$ & $\begin{array}{l}3958.0 \\
(377.2)\end{array}$ \\
\hline 8 & $\begin{array}{l}3833.0 \\
(726.1)\end{array}$ & $\begin{array}{l}4159.0 \\
(72.1)\end{array}$ & $\begin{array}{l}3085.3 \\
(912.0)\end{array}$ & $\begin{array}{l}3734.5 \\
(771.5)\end{array}$ & $\begin{array}{l}2845.5 \\
(557.9)\end{array}$ & $\begin{array}{l}3114.8 \\
(596.3)\end{array}$ \\
\hline 12 & $\begin{array}{l}3045.0 \\
(506.2)\end{array}$ & $\begin{array}{l}2574.5 \\
(408.0)\end{array}$ & $\begin{array}{l}3132.2 \\
(741.7)\end{array}$ & $\begin{array}{l}3767.0 \\
(325.3)\end{array}$ & $\begin{array}{l}2983.0 \\
(528.9)\end{array}$ & $\begin{array}{l}3393.2 \\
(795.3)\end{array}$ \\
\hline 16 & $\begin{array}{l}3615.0^{\circ} \\
(472.5)\end{array}$ & $\begin{array}{l}3492.0 \\
(490.7)\end{array}$ & $\begin{array}{c}4494.0 \\
(1512.5)\end{array}$ & $\begin{array}{l}3500.5 \\
(784.2)\end{array}$ & $\begin{array}{l}3674.5 \\
(668.2)\end{array}$ & $\begin{array}{l}3949.4 \\
(560.4)\end{array}$ \\
\hline Females & $(n=3)$ & $(n=4)$ & $(\mathrm{n}=3)$ & $(n=4)$ & $(n=4)$ & $(\mathrm{n}=1)$ \\
\hline 1 & $\begin{array}{l}2649.0 \\
(311.0)\end{array}$ & $\begin{array}{l}3460.8 \\
(777.0)\end{array}$ & $\begin{array}{l}3857.0 \\
(319.5)\end{array}$ & $\begin{array}{l}3420.3 \\
(782.8)\end{array}$ & $\begin{array}{l}3953.8 \\
(702.1)\end{array}$ & 3552.0 \\
\hline 2 & $\begin{array}{l}3638.3 \\
(348.4)\end{array}$ & $\begin{array}{l}3864.0 \\
(751.3)\end{array}$ & $\begin{array}{l}2986.7 \\
(616.2)\end{array}$ & $\begin{array}{l}4185.5 \\
(742.6)\end{array}$ & $\begin{array}{c}4317.8 \\
(1596.9)\end{array}$ & 3138.0 \\
\hline 3 & $\begin{array}{l}3968.0 \\
(362.2)\end{array}$ & $\begin{array}{l}3611.0 \\
(725.4)\end{array}$ & $\begin{array}{c}3091.0 \\
(1047.2)\end{array}$ & $\begin{array}{l}3573.3 \\
(639.1)\end{array}$ & $\begin{array}{l}4185.5 \\
(307.1)\end{array}$ & 4094.0 \\
\hline 4 & $\begin{array}{c}3535.3 \\
(81.8)\end{array}$ & $\begin{array}{l}3485.5 \\
(950.7)\end{array}$ & $\begin{array}{l}4065.0 \\
(598.8)\end{array}$ & $\begin{array}{l}3962.3 \\
(406.2)\end{array}$ & $\begin{array}{l}4315.8 \\
(353.3)\end{array}$ & 4374.0 \\
\hline 8 & $\begin{array}{l}3990.0 \\
(412.0)\end{array}$ & $\begin{array}{c}2640.5 \\
(1052.8)\end{array}$ & $\begin{array}{l}3197.0 \\
(254.7)\end{array}$ & $\begin{array}{c}3101.3 \\
(1565.9)\end{array}$ & $\begin{array}{l}3914.5 \\
(303.4)\end{array}$ & 4277.0 \\
\hline 12 & $\begin{array}{l}3016.3 \\
(440.1)\end{array}$ & $\begin{array}{l}2796.5 \\
(476.9)\end{array}$ & $\begin{array}{l}3186.0 \\
(372.7)\end{array}$ & $\begin{array}{l}3260.5 \\
(385.0)\end{array}$ & $\begin{array}{l}3691.3 \\
(436.7)\end{array}$ & 3845.0 \\
\hline 16 & $\begin{array}{l}3813.5 \\
(768.6)\end{array}$ & $\begin{array}{l}321.9 .5 \\
(728.4)\end{array}$ & $\begin{array}{c}4291.7 \\
(1746.7)\end{array}$ & $\begin{array}{l}3803.0 \\
(738.2)\end{array}$ & $\begin{array}{c}4069.3 \\
(1033.7)\end{array}$ & 2201.0 \\
\hline
\end{tabular}

Table 5. Mediomastus ambiseta. Results of a 3-factor (treatment, gender and time) repeated measures ANOVA on number of setigers in the second feeding experiment

\begin{tabular}{|lrrrc|}
\hline Source & df & MS & F-ratio & $p$ \\
\hline Treatment & 5 & 157.72 & 1.94 & 0.127 \\
Gender & 1 & 78.25 & 0.96 & 0.337 \\
Treatment $\times$ Gender & 5 & 84.21 & 1.04 & 0.421 \\
Worms & 23 & 81.33 & & \\
Time & 1 & 2597.72 & 221.03 & $0.000 \cdots$ \\
Treatment $\times$ Time & 5 & 7.46 & 0.64 & 0.675 \\
Gender $\times$ Time & 1 & 96.86 & 8.24 & $0.009 \cdots$ \\
Treat. $\times$ Gend. $\times$ Time & 5 & 16.42 & 1.40 & 0.262 \\
Error & 23 & 11.75 & & \\
$\cdots 0.01>p>0.001 ; \cdots p<0.001$ & & & \\
\hline
\end{tabular}

time interaction or significant treatment-by-time-bygender interaction (Table 5).

The number of tubes and number of tube openings a worm produced at the end of these experiments were not different; most worms had only 1 or 2 openings per tube. Consequently, only the number of tube openings at the end of each feeding experiment was used to test for differences in tube-building behavior between treatments. In the first feeding experiment, no significant difference between treatments in the mean number of tube openings was detected (1-way ANOVA, data log transformed to homogenize variances; $F_{3,16}=$ $0.612, p=0.62$ ) (Fig. 2). Tube production did not differ between treatments at the end of the second feeding experiments (2-way ANOVA, log transformed data; 
Table 6. Mediomastus ambiseta. Mean (SD) number of setigers in each treatment and gender at the start and end of the second feeding experiment; sample size (n) at the start of the experiment is the same as at the end of the experiment

\begin{tabular}{|c|c|c|c|c|c|c|c|}
\hline \multirow{3}{*}{$\begin{array}{l}\text { Treatment } \\
\text { Control }\end{array}$} & \multicolumn{3}{|c|}{ Males } & \multicolumn{4}{|c|}{ Females } \\
\hline & Start & \multicolumn{2}{|c|}{ End } & \multicolumn{2}{|c|}{ Start } & \multicolumn{2}{|c|}{ End } \\
\hline & $\begin{array}{l}53.0 \\
\mathrm{n}=3\end{array}$ & 66.0 & $(6.6)$ & $\begin{array}{l}62.0 \\
\mathrm{n}=3\end{array}$ & $(5.6)$ & 76.3 & (7.1) \\
\hline $0.1 \%$ barite & $\begin{array}{l}54.0 \\
n=2\end{array}$ & 63.0 & $(8.5)$ & $\begin{array}{l}49.3 \\
n=4\end{array}$ & $(8.3)$ & 62.3 & $(13.7)$ \\
\hline $1.0 \%$ barite & $\begin{array}{l}55.0 \\
\mathrm{n}=2^{\mathrm{a}}\end{array}$ & 67.5 & $(10.6)$ & $\begin{array}{l}60.3 \\
n=3\end{array}$ & $(5.0)$ & 72.7 & $(8.0)$ \\
\hline $10 \%$ barite & $\begin{array}{l}54.5 \\
\mathrm{n}=2\end{array}$ & 64.5 & $(0.7)$ & $\begin{array}{l}51.5 \\
n=4\end{array}$ & $(6.2)$ & 66.5 & (5.7) \\
\hline $50 \%$ barite & $\begin{array}{l}48.0 \\
n=2\end{array}$ & 55.0 & $(4.2)$ & $\begin{array}{l}48.3 \\
n=4\end{array}$ & $(3.7)$ & 69.3 & $(5.6)$ \\
\hline $\begin{array}{l}1 \mathrm{~mm} \text { barite } \\
\text { layer }\end{array}$ & $\begin{array}{l}52.4 \\
\mathrm{n}=5\end{array}$ & 65.6 & $(4.2)$ & $\begin{array}{l}44.0 \\
n=1\end{array}$ & & 64.0 & \\
\hline
\end{tabular}

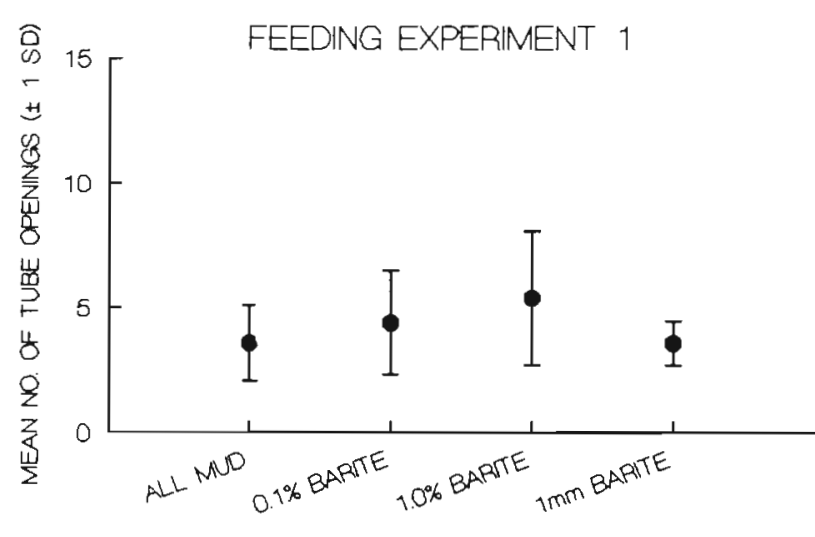

TREATMENT

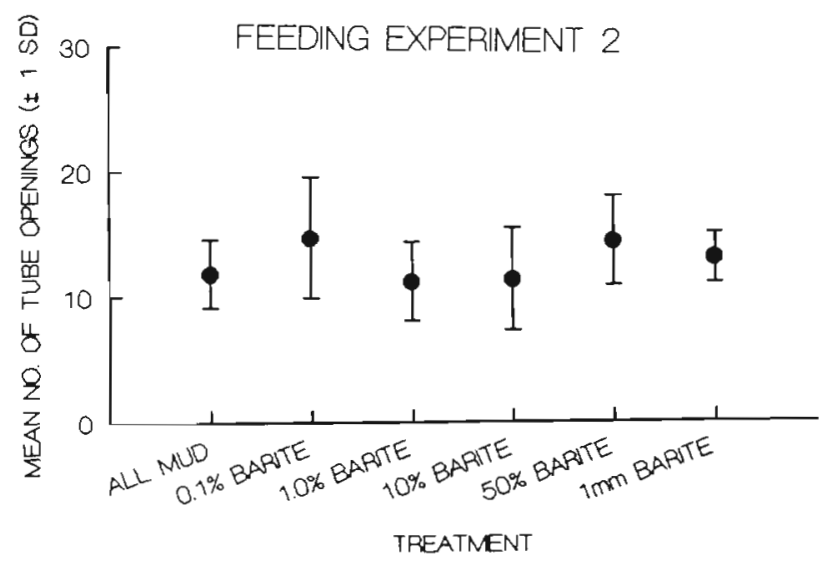

Fig. 2. Mediomastus ambiseta. Mean and SD of the number of tube openings produced per worm in each treatment at the end of the 2 feeding experiments. Tube openings produced by males and females were combined in the second feeding experiment
$F_{5,24}=0.785, p=0.57$ ) (Fig. 2), nor was there a difference in mean number of tube openings between males and females $\left(F_{1,24}=0.061, p=0.81\right)$ or a significant treatment-by-gender interaction $\left(F_{5,24}=0.713, \mathrm{p}=\right.$ $0.62)$.

Only 2 treatments in the first feeding experiment, control and $0.1 \%$ barite, had replicate sample measurements of total microbial biomass at the start and at the end of the experiment (Table 7). In these 2 treatments, total microbial biomass at the start of the first feeding experiment was significantly greater than at the end of the experiment (univariate, 2-factor ANOVA model with repeated measures on the factor time, data log transformed; time effect, $F_{1.8}=38.71$, $\mathrm{p}=0.0003$ ) (Table 3 ). There was no significant difference in total microbial biomass between treatments (treatment, $F_{1,8}=3.085, \mathrm{p}=0.12$ ) nor was there a significant treatment-by-time interaction $\left(F_{1,8}=0.166\right.$, $\mathrm{p}=0.69)$.

At the end of the experiment, total microbial biomass in the $1 \mathrm{~mm}$ barite cover was not significantly different from biomass in the mud underneath (paired $t$-test, $\mathrm{df}=4, t=2.39, \mathrm{p}=0.08$ ) (Table 7 ). The mean total microbial biomass at the end of the experiment was compared between treatments: control, $0.1 \%$ barite, $1.0 \%$ barite and the mud underneath the $1 \mathrm{~mm}$ barite cover. The mud under the $1 \mathrm{~mm}$ barite cover was included in the analysis because the migration experiment showed that worms fed in mud beneath barite, but not in the overlying barite. No significant difference in biomass was detected between treatments (1-way ANOVA, data were - $(1 / x)$ transformed to homogenize variances; $F_{3,16}=0.745$, $p=0.54)$. 
Table 7. Mean (SD) total microbial biomass (nmol phospholipid phosphate $\mathrm{cm}^{-3}$ ) for each treatment at the start (before worms were added) and end of the first feeding experiment. Onily 1 sample was measured at the start of the experiment in the $1.0 \%$ barite treatment. No samples were taken in the 1 $\mathrm{mm}$ barite layer treatment at the start of the experiment.

Sample size is 5 for all other treatments, $\mathrm{n}=5$

\begin{tabular}{|c|c|c|}
\hline \multirow{3}{*}{$\begin{array}{l}\text { Treatment } \\
\text { Control }\end{array}$} & \multicolumn{2}{|c|}{ Phospholipid phosphate (nmol $\mathrm{cm}^{-3}$} \\
\hline & Start & End \\
\hline & $26.82 \quad(7.71)$ & $14.79(4.61)$ \\
\hline $0.1 \%$ barite & $19.80 \quad(4.06)$ & $11.62(1.85)$ \\
\hline $1.0 \%$ barite & 17.63 & $12.16 \quad(0.75)$ \\
\hline $\begin{array}{l}1 \mathrm{~mm} \text { barite } \\
\text { layer }\end{array}$ & - & $19.09(7.13)$ \\
\hline $\begin{array}{l}\text { Mud underneath } \\
1 \mathrm{~mm} \text { barite }\end{array}$ & - & $11.51 \quad(3.82)$ \\
\hline
\end{tabular}

\section{Growth experiment}

One worm in the control could not be found at the end of the experiment; it had stopped producing tubes and fecal pellets $24 \mathrm{~d}$ before the experiment ended. All 5 worms were recovered from the $10 \%$ barite dishes, but 1 worm was regenerating a tail and was not included in the analysis for growth differences between treatments.

Worms grew in both treatments $\left(F_{1,6}=67.22, \mathrm{p}=\right.$ $0.0002)$; at the start of the experiment, the mean setiger number per worm was $36.3 \pm 2.5$ in the control and $34.3 \pm 4.1$ in $10 \%$ barite. After $8 \mathrm{wk}$, the mean number of setigers was $52.5 \pm 3.3$ in the control and $54.8 \pm 12.6$ in $10 \%$ barite. $(n=4$ for all these means because the

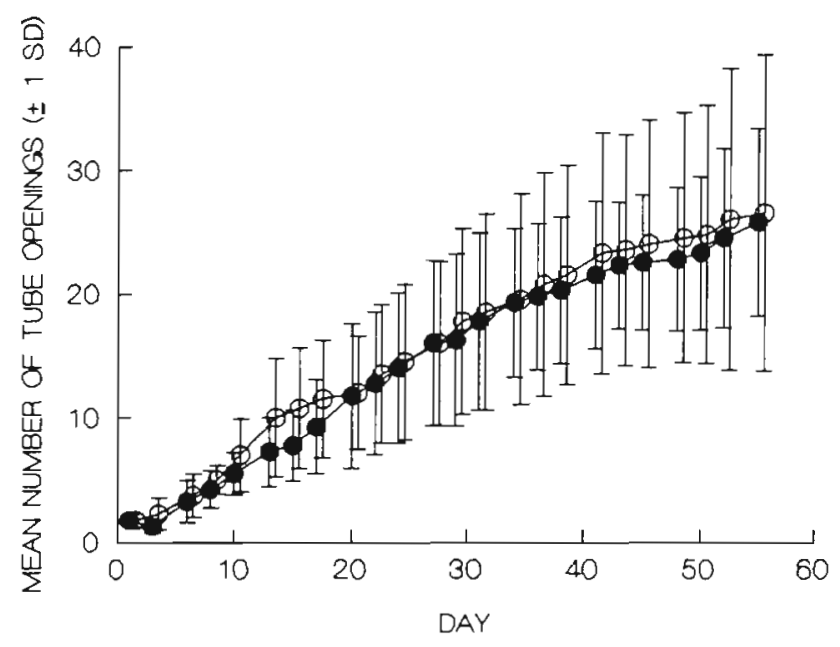

Fig. 3. Mean and SD of the number of tube openings produced per worm in ( ) the control treatment and $(0)$ the $10 \%$ barite treatment during the growth experiment; $n=4$ for each treatment regenerating worm in $10 \%$ barite and the lost worm in the control were not included in the computations.) Growth did not differ significantly between treatments $\left(F_{1,6}=0.05, \mathrm{p}=0.83\right)$; the time-by-treatment interaction was not significant $\left(F_{1,6}=0.728, \mathrm{p}=0.43\right)$.

Worms produced visible gametes in both treatments. One of the 4 worms retrieved from the control treatment had male gametes. Of the 5 worms in the $10 \%$ barite treatment, there were 2 males, 1 female and 2 worms lacking gametes. In $10 \%$ barite, 1 worm became inactive $1 \mathrm{wk}$ before the experiment ended, and another worm stopped producing pellets $3 \mathrm{~d}$ before the experiment ended. Analysis of tube-building behavior was performed on the number of tubes and tube openings found in each dish $1 \mathrm{wk}$ before the experiment ended when the maximum number of worms was active. There was no significant difference in number of tube openings between the 2 treatments (2-sample $t$-test, data log transformed; $\mathrm{df}=7, t=0.664, \mathrm{p}=0.53$ ) (Fig. 3). At the end of the experiment, worms had made an average of $1.8 \pm 0.5(n=4)$ openings per tube in the control dishes and $1.8 \pm 0.1(n=5)$ openings per tube in $10 \%$ barite.

\section{DISCUSSION}

The only effect of barite on Mediomastus ambiseta detected in this study was that worms avoided and did not feed in $100 \%$ barite. Worms may have left $100 \%$ barite because food for deposit-feeders, i.e. microbes and nonliving organic matter such as detritus and dissolved molecules (Lopez \& Levinton 1987, Taghon \& Greene 1990), was in low abundance relative to the organic-rich natural mud. Although total microbial biomass and detritus were not measured in the migration experiment, they were likely to be less in $100 \%$ barite than in the control. Approximately $26 \%$ of barite particles were less than $8 \mu \mathrm{m}$ (Findlay, Kim \& Butman unpubl.) and, hence, were in the category of sediment particles ( $\leq 10 \mu \mathrm{m}$ in diameter) that are rarely colonized by bacteria (Hargrave 1972, DeFlaun \& Mayer 1983). In fact, using mud from Buzzards Bay, Massachusetts, Findlay, Kim \& Butman found lower total microbial biomass in $100 \%$ barite overlying mud than in exposed mud after $2 \mathrm{wk}$ in flowing seawater. Consistent with the suggestion that $M$. ambiseta migrated out of barite because of low food quality is the migration of a deposit-feeding polychaete from areas where detrital food had been removed (Weinberg 1979).

There was some indication in the migration experiment that worms avoided $10 \%$ barite because there was significantly less worm movement from all mud into $10 \%$ barite than in the control dishes (all mud to 
all mud). If $10 \%$ barite had an adverse effect on worms, however, we expected that worms should also show significant movement out of $10 \%$ barite, but they did not. Because no effect on worm feeding rate, tube production and growth was observed for worms in sediments containing $10 \%$ barite, it is doubtful that worm avoidance of $10 \%$ barite was as strong a response as worm avoidance to $100 \%$ barite.

The feeding experiments, which used number of fecal pellets produced $\mathrm{d}^{-1}$ as a proxy for feeding rate, did not demonstrate any effect of barite in concentrations as high as $50 \%$. Number of fecal pellets, however, is not the only measure of sediment processing that could have been affected by barite. If worms process more sediment to make up for reduced food concentrations in sediments containing barite, then worms may have made larger or denser fecal pellets, but not changed the number of fecal pellets produced. It is not known whether Mediomastus ambiseta can alter pellet size or weight with varying sediment quality (e.g. Taghon et al. 1984). In Capitella sp. I, however, small worms make denser pellets than large worms, but number of pellets produced does not change with worm size (Forbes \& Lopez 1987). The effect of worm size on pellet production was controlled for in both feeding experiments; sizes of worms did not differ between treatments.

Another way deposit feeders can control feeding rates is by adjusting residence times of sediment in the gut to the quality or concentration of food in the sediments (Lopez \& Levinton 1987, Dade et al. 1990, Penry \& Jumars 1990). Gut-residence times were not measured for Mediomastus ambiseta, but it is possible that residence times may correlate with reduced food quality or food concentration in sediments containing barite. Thus, although our results indicate that barite does not affect adult-worm measurements of pellet production, pellet weights and gut-residence times in control, natural, muddy sediments and sediments containing barite are required to definitively assess the effect of barite on feeding rates of $M$. ambiseta exposed to high concentrations of drilling muds in natural environments.

Total microbial biomass, a measure of food quality, in control and barite sediments was measured only in the first feeding experiment. The results indicate that total microbial biomass was reduced in the control and $0.1 \%$ barite after $6 \mathrm{~d}$. This reduction in biomass may be the result of worm sediment reworking, or it may indicate that the bacteria were not in a suitable environment for population growth. Total microbial biomass did not differ between the control and $0.1 \%$ barite which suggests that barite in concentrations as low as $0.1 \%$ may not affect the food quality of the sediment. We have no measure of total biomass in higher concentrations of barite before worms were placed in dishes. Consequently, we cannot separate the effects of the worms on microbial biomass from possible differences among barite concentrations (i.e. $1.0 \%$ barite and $1 \mathrm{~mm}$ barite cover) in interpreting the result that microbial biomass did not differ between any of the treatments at the end of the experiment.

Assuming that the $1 \mathrm{~mm}$ barite cover over mud had much less microbial biomass than the mud underneath before worms were added (Findlay, Kim \& Butman unpubl.), then it is likely that worm feeding and sediment reworking resulted in no difference between the barite surface layer and the mud underneath in microbial biomass after $7 \mathrm{~d}$ of worm activity. Although our measurements of microbial biomass in the $1 \mathrm{~mm}$ barite cover treatment included the effects of worms, our results agree with Smith et al. (1982), who found that 1 or $2 \mathrm{~mm}$ layers of barite over sand had no consistent effect on microbial biomass or community structure.

It is not known why Mediomastus ambiseta build tubes with multiple openings. It may be to increase oxygen in the tube, or for greater access to the surface sediments to deposit fecal pellets, or to release gametes. Whatever the reasons, the number of tube openings that worms produced was not affected by barite in our experiments.

Worms grew in both experiments where growth was measured; hence, the duration of the experiments was sufficient to detect growth differences. Barite, however, did not result in decreased growth rate of worms in either experiment. This result suggests that barite in concentrations reported from drilling areas (see 'Introduction') is not likely to affect the growth of adult Mediomastus ambiseta. Growth of the clam Laevicardium mortoni also did not appear to be affected by barite after $10 \mathrm{wk}$ in $1: 10$ and $1: 3$ parts barite in sand and $1 \mathrm{~mm}$ barite cover over sand; however, no statistical analysis of these data was presented (Tagatz \& Tobia 1978).

Survival of worms in barite, although not specifically tested in our experiments, was high in the feeding and growth experiments. All worms survived in sediments containing barite in the 2 feeding experiments. Only 1 worm died in the growth experiment and that worm was in the control. All experiments in this study, however, were conducted with adults, which may not be as sensitive as juveniles to effects of barite. Newly settled deposit-feeding juveniles may consume a higher proportion of smaller particles (Jumars et al. 1990). Furthermore, because of their faster growth rates and energetic constraints, juveniles may be more influenced by subtle variations in food resources than are adults.

A limitation of our experiments was that sample sizes were small, and consequently the statistical tests had low statistical power to detect small differences be- 
tween the means of the treatments and the mean of the control. For example, consider the mean number of setigers added in the growth experiment. To detect a significant difference between the $10 \%$ barite treatment and the control, a difference of 19 added setigers was required. (This difference was computed from power calculations for a 2-sample $t$-test with $\mathrm{n}_{1}=\mathrm{n}_{2}=$ $4, \mathrm{df}=6, \sigma=7.7, \alpha=0.05$ and power $=0.80$ for a 2 -sided alternative; Devore 1991.) This difference was much greater than the observed difference of 5 setigers added between the mean of the $10 \%$ barite treatment and the mean of the control. Furthermore, a difference of 19 setigers was greater than the mean number of setigers added after $8 \mathrm{wk}$ in the control (i.e. 16 setigers) and was only slightly less than the 21 setigers that were added in the $10 \%$ barite treatment. Although the statistical test on the data from growth experiment was not sensitive enough to detect small growth differences between the treatment and the control, the resuits of this experiment were consistent with the results of the second feeding experiment in which growth was measured after $18 \mathrm{~d}$. No difference in growth between the control and barite treatments was detected in the second feeding experiment. Notice that the experimental design of the second feeding experiment was sensitive enough to detect a difference between male and female worms in the number of added setigers.

The sample size used in the second feeding experiments was not sufficient to test for small differences between the control and any barite treatment. If the alternative hypothesis was true, we could only detect this for our sample sizes if the difference between the maximum mean and minimum mean of the 6 treatments was greater than 2904 pellets. (Computations are based on a 1-way ANOVA with a power $=0.80, k=$ $6, \mathrm{n}=6, \sigma=1290$ and for a small effect size, sensu Cohen 1977.) To detect a medium effect, sensu Cohen (1977), a difference of 2455 fecal pellets was necessary. Although the mean difference between the control and any barite treatment was smaller than these values (Table 6), the results of the second feeding experiment agreed with the first feeding experiment. That is, there was no difference between the control and any barite treatment in the mean number of fecal pellets produced. The consistency of the results between the experiments suggests that worm growth and pellet production were not different between control and barite treatments in the feeding experiments and growth experiments.

Non-barite components of drilling muds were not investigated in our study, but may affect Mediomastus ambiseta abundances near drilling sites. Non-barite components are toxic to some organisms (e.g. Carls \& Rice 1984, Neff 1987, Macdonald et al. 1988) and have been shown to reduce abundances of some species in colonization studies (Tagatz et al. 1978). Our experiments with barite suggest that in concentrations of $10 \%(104 \mathrm{ppm})$ or less, by weight, barite does not appreciably affect movement, pellet production rate, tube production or growth of adult $M$. ambiseta. Thus, it is unlikely that the barite portion of drilling muds will significantly affect adult $M$. ambiseta densities in drilling areas.

Acknowledgements. We thank N. Y. Trowbridge, J. K. Hahn and $R$. F. Petrecca for their assistance with experiments. The U.S. Geological Survey performed sediment grain-size analysis on barite. E. R. Zettler and M. Brezinski helped with the Coulter Counter. R. H. Findlay analyzed samples for total microbial biomass, and S. L. Kim obtained the data for the regressions used to compute volume of sediment for each sample. N. Y. Trowbridge and S. J. Bowman typed portions of the manuscript. Comments by D. F. Boesch, J. P. Grassle, P. A. Jumars and J. R. Weinberg improved the manuscript. This study was supported by the Minerals Management Service (U.S. Department of the Interior) Contract No. 14-12-0001300262 to C.A.B. This is WHOI contribution number 7988 .

\section{LITERATURE CITED}

Ayers, R. C. Jr., Sauer, T. C. Jr., Meek, R. P., Bowers, G. (1980). An environmental study to assess the effects of drilling discharges in the Mid-Atlantic. I. Quantity and fate of discharges. In: Symposium/research on environmental fate and effects of drilling fluids and cuttings. American Petroleum Institute, Washington, DC, p. 382-418

Bachelet, G., Butman, C. A., Webb, C. M., Starczak, V. R., Snelgrove, P. V. N. (in press). Non-selective settlement of Mercenaria mercenaria (Linné) larvae in short-term, stillwater, laboratory experiments. J. exp. mar. Biol. Ecol.

Boothe, P. N., Presley, B. J. (1985). Distribution and behavior of drilling fluids and cuttings around Gulf of Mexico drilling sites. Report to American Petroleum Institute, Environmental Affairs Dept., Washington, DC

Cantelmo, F. R., Tagatz, M. E., Ranga Rao, K. (1979). Effect of barite on meiofauna in a flow-through experimental system. Mar. environ. Res. 2: 301-309

Carls, M. G., Rice, S. D. (1984). Toxic contributions of specific drilling mud components to larval shrimp and crabs. Mar. environ. Res. 12: 45-62

Cohen, J. (1977). Statistical power analysis for the behavioral sciences. Academic Press, Orlando

Dade, W. B., Jumars, P. A., Penry, D. L. (1990). Supply-side optimization: maximizing absorptive rates. In: Hughes, R. N. (ed.) Behavioural mechanisms of food selection, NATO ASI Series, Vol. G20. Springer-Verlag, Berlin, p. $521-556$

Dauer, D. M., Simon, J. L. (1976a). Repopulation of the polychaete fauna of an intertidal habitat following natural defaunation: species equilibrium. Oecologia 22: 99-117

Dauer, D. M., Simon, J. L. (1976b). Habitat expansion among polychaetous annelids repopulating a defaunated marine habitat. Mar. Biol. 37: 169-177

DeFlaun, M. F. Mayer, L. M. (1983). Relationships between bacteria and grain surfaces in intertidal sediments. Limnol. Oceanogr. 28: 873-881 
Devore, J L. (1991). Probability and statistics for engineering and the sciences. Brooks/Cole Publishing Co., Pacific Grove

Findlay, R, H., King, G. M., Watling, L. (1989). Efficacy of phospholipid analysis in determining microbial biomass in sediments. Appl. environ. Microbiol. 54: 2888-2893

Forbes, T. L., Lopez, G. R. (1987). The allometry of deposit feeding in Capitella species I (Polychaeta: Capitellidae): the role of temperature and pellet weight in the control of egestion. Biol. Bull. 172: 187-201

Fuller, C. M., Butman, C. A., Conway, N. M. (1988). Periodicity in fecal pellet production by the capitellid polychaete Mediomastus ambiseta throughout the day. Ophelia 29: 83-91

Germano, J. D. (1983). Infaunal succession in Long Island Sound: animal-sediment interactions and the effects of predation. Ph.D. dissertation, Yale University.

Gettleson, D. A., Laird, C. E. (1980). Benthic barium levels in the vicinity of six drill sites in the Gulf of Mexico. In: Symposium/research on environmental fate and effects of drilling fluids and cuttings. American Petroleum Institute, Washington, DC, p. $739-788$

Grant, W. D., Butman C. A. (1987). The effects of size class and bioturbation on fine-grained transport in coastal systems: specific application to biogeochemistry of $\mathrm{PCB}$ transport in New Bedford Harbor. In: White, A. W., Petrovits, A. W. (eds.) 1984-1987 Sea Grant Program Report. Woods Hole Oceanographic Institution, Woods Hole, p. 15-17

Grassle, J. F., Grassle, J. P. (1974). Opportunistic life histories and genetic systems in marine benthic polychaetes. $\mathrm{J}$ mar. Res. 32: 253-284

Grassle, J. P., Grassle J. F. (1984). The utility of studying the effects of pollutants on single species populations in benthos of mesocosms and coastal ecosystems. In: White H. H. (ed.) Concepts in marine pollution measurements Maryland Sea Grant Program, College Park, p. 621-642

Hargrave, B. T. (1972). Aerobic decomposition of sediment and detritus as a function of particle surface area and organic content. Limnol. Oceanogr. 17: 583-596

Hyland, J., Baptiste, E., Campbell, J., Kennedy, J., Kropp, R. Williams, S. (1991). Macroinfaunal communities of the Santa Maria Basin on the continental shelf and slope. Mar Ecol. Prog. Ser. 78: 147-161

Hyland, J., Hardin, D., Crecelius, E., Drake, D., Montagna, P., Steinhauer, M. (1990). Monitoring long-term effects of offshore oil and gas development along the Southern California outer continental shelf and slope: background environmental conditions in the Santa Maria Basin. Oil Chem. Pollut. 6: 195-240

Jumars, P. A., Mayer, L. M., Deming, J. W., Baross, J. A., Wheatcroft, R. A. (1990). Deep-sea deposit-feeding strategies suggested by environmental and feeding constraints. Phil. Trans. R. Soc. (Ser. A) 331: 85-101

Lopez, G. R., Levinton, J. S. (1987). Ecology of deposit-feeding animals in marine sediments. Q. Rev. Biol. 62: 235-259

Macdonald, J. M., Shields, J. D., Zimmer-Faust, R. K. (1988). Acute toxicities of eleven metals to early life-history stages of the yellow crab Cancer anthonyi. Mar. Biol. 98: 201-207

McGlothlin, R. E., Krause, H. (1980). Water base drilling fluids. In: Symposium/research on environmental fate and effect of drilling fluids and cuttings. American Petroleum Institute, Washington, DC, p. 30-37

Miller, D. C., Jumars P. A. (1986). Pellet accumulation, sediment supply, and crowding as determinants of surface deposit-feeding rate in Pseudopolydora kempi japonica Imajima \& Hartman (Polychaeta: Spionidae). J. exp. mar.
Biol. Ecol. 99: 1-17

National Research Council (1983). Drilling discharges in the marine environment. National Academy Press, Washington, DC

Neff, J. M. (1987). Biological effects of drilling fluids, drill cuttings and produced waters. In: Boesch, D. F., Rabalais, N. N. (eds.) Long-term environmental effects of offshore oil and gas development. Elsevier Applied Science, New York, p. 469-536

Neff, J. M., Bothner, M. H., Maciolek, N. J., Grassle, J. F. (1989). Impacts of exploratory drilling for oil and gas on the benthic environment of Georges Bank. Mar. environ. Res. 27: 77-114

Neff, J. M., Rabalais, N. N., Boesch, D. F. (1987). Offshore oil and gas development activities potentially causing longterm environmental effects. In: Boesch, D. F., Rabalais, N. N. (eds.) Long-term environmental effects of offshore oil and gas development. Elsevier Applied Science, New York, p. 149-174

Oviatt, C., Frithsen J., Gearing, J., Gearing, P. (1982). Low chronic additions of No. 2 fuel oil: chemical behavior, biological impact and recovery in a simulated ecosystem. Mar. Ecol. Prog. Ser. 9: 121-136

Pearson, T.H., Rosenberg, R. (1978). Macrobenthic succession in relation to organic enrichment and pollution of the marine environment. Oceanogr. mar. Biol. A. Rev. 229-311

Penry, D. L., Jumars P. A. (1990). Gut architecture, digestive constraints and feeding ecology of deposit-feeding and carnivorous polychaetes. Oecologia 82: 1-11

Periconne, C. (1980). Major drilling fluid additives - 1979. In: Symposium/research on environmental fate and effects of drilling fluids and cuttings. American Petroleum Institute. Washington, DC, p. 15-29

Petrazzuolo, G. (1983). Environmental assessment: drilling fluids and cuttings released onto the OCS. Draft final technical report document submitted to Office of Water Enforcement and Permits, U. S. Environmental Protection Agency, Washington, DC by Technical Resources, Inc., Bethesda, Maryland

Rasmussen, E., (1956). Faunistic and biological notes on marine invertebrates. III. The reproduction and larval development of some polychaetes from Isefjord, with some faunistic notes. Biol. Meddr 23: 1-84

Sanders, H. L., Grassle, J. F., Hampson, G. R., Morse, L. S., Garner-Price, S., Jones, C. C. (1980). Anatomy of an oil spill: long-term effects from the grounding of the barge Florida off West Falmouth, Massachusetts. J. mar. Res. 38: $265-380$

Smith, G. A., Nickels, J. S., Bobbie, R. J., Richards, N. L., White, D. C. (1982). Effects of oil and gas well-drilling fluids on the biomass and community structure of microbiota that colonize sands in running seawater. Archs environ. Contam. Toxicol. 11: 17-23

Tagatz, M. E., Ivey, J. M., Lehman, H. K., Oglesby, J. L. (1978). Effects of a lignosulfonate-type drilling mud on development of experimental estuarine macrobenthic communities. NE Gulf Sci. 2: $35-42$

Tagatz, M. E., Tobia, M. (1978). Effect of barite $\left(\mathrm{BaSO}_{4}\right)$ on development of estuarine communities. Estuar coast. mar. Sci. 7: 401-407

Taghon, G. L., Greene R. R. (1990). Effects of sedimentprotein concentration on feeding and growth rates of Abarenicola pacifica Healy et Wells (Polychaeta: Arenicolidae). J. exp. mar. Biol. Ecol. 136: 197-216

Taghon, G. L., Jumars, P. A. (1984). Variable ingestion rate and its role in optimal foraging behavior of marine deposit-feeders. Ecology 65: 549-558 
Taghon, G. L., Nowell, A. R. M., Jumars P. A. (1984). Transport and breakdown of fecal pellets: biological and sedimentological consequences. Limnol. Oceanogr. 29: $64-72$

Weinberg, J. R. (1979). Ecological determinants of spionid dis-

This article was submitted to the editor tributions within dense patches of deposit-feeding polychaete Axiothella rubrocincta. Mar. Ecol. Prog. Ser. 1: $301-314$

Winer, B. J. (1971). Statistical principals in experimental design. McGraw-Hill, New York

Manuscript first received: April 4, 1992

Revised version accepted: June 30, 1992 